\section{Attitudes toward risk, social dominance orientation and perceived scarcity of the opposite sex on Indonesian woman migrant workers}

Rizkytha, Innes Zia

Department of Psychology, Bina Nusantara University, Indonesia (inneszial8@gmail.com)

Abraham, Juneman

Department of Psychology, Bina Nusantara University, Indonesia (juneman@binus.edu)

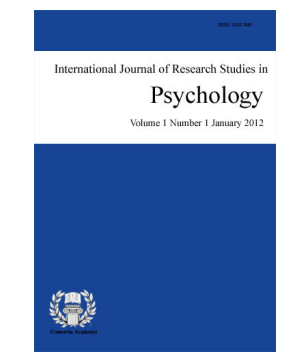

ISSN: $2243-7681$ Online ISSN: 2243-769X

OPEN ACCESS

Received: 6 January $2015 \quad$ Revised: 18 January $2015 \quad$ Accepted: 4 February 2015

Available Online: 22 February $2015 \quad$ DOI: $10.5861 /$ ijrsp.2015.1051

\title{
Abstract
}

This study aimed to determine the role of social dominance orientation and perceived scarcity of the opposite sex in predicting attitudes toward risks on Indonesian Woman Migrant Workers (IWMW) that will work abroad. The design used for this study was quantitative non-experimental and predictive correlational by using psychological scales as the measuring instrument. This study involved 258 unmarried IWMW $\left(M_{\text {age }}=20.089\right.$ years old; $S D_{\text {age }}=$ 5.142 years) fostered by National Agency for the Placement and Protection of IWMW (BNP2TKI) and those in the shelters. Result of the study shows that social dominance orientation and perceived scarcity of the opposite sex can predict attitudes toward risks on IWMW $\left(R^{2}=0.343\right)$. Social dominance orientation is able to positively predict attitudes toward risks $(\beta=0.618 ; p<0.01)$ and perception of the number of opposite sex is able to negatively predict attitudes toward risks $(\beta=-0.159 ; p<0.01)$.

Keywords: social dominance; risks; woman workers; sex ratio; Indonesia 


\section{Attitudes toward risk, social dominance orientation and perceived scarcity of the opposite sex on Indonesian woman migrant workers}

\section{Introduction}

Indonesian Woman Migrant Workers (IWMW), in addition to facing difficult requirements, also must deal with the various risks and threats (Handayani, 2012). The increasing number of IWMW is not followed with optimum protection by the national government, whereas IWMW are part of the most vulnerable groups in Indonesia. The risks faced by IWMW among others are accident at work, illness, unpaid salary, problematic employment, and unpaid insurance claim (SapulidiNews, 2014), various transnational crimes especially human trafficking, and another injustice such as mistreatment and oppression (Emmers, 2003); dismissal within work contract period, bodily wounds, sexual harassment, or even death (Utami, 2012); prison sentence and disappearance (Kistyarini, 2013); HIV and social isolation (Shehadeh \& McCoy, 2014) occurring in Saudi Arabia, Malaysia, Taiwan, Hong Kong, and other countries.

This study assumed that one's intention to be IWMW can be linked to her attitude toward risks or risk attitude. A person does not know when they will happen, but she also cannot be certain whether they will happen (Crozier, Ranyard, \& Svenson, 2002). Risk is "exposure to a proposition of which one is uncertain" (Holton, 2004, p. 22). Attitude toward risk involves consideration between detrimental outcomes (loss frame) and profitable outcomes (gain frame) (Johnson, 2009). The risks described above do not diminish the interest of Indonesian women to work as migrant workers. The migration phenomena by becoming IWMW can be explained from several perspectives. The classic migration theory by Everett S. Lee (as cited in Mashud, 2010) explains that the decision to migrate abroad is a consequence of the differences in benefits between of place of origin and place of destination. Place of origin that is considered less favorable becomes the "push factor", and this condition causes stress and intense pressure to migrate. Becoming IWMW is the "pull factor" because it is considered promising. However, study conducted by Weber et al. (as cited in Harris \& Jenkins, 2006) found that women tend to engage in risky behavior where on the whole they "feel" great benefit from practices that contain risks. Becoming IWMW is somehow taken as a result of "beyond a rational calculation", a term derived from Kahneman (2011) and Tversky and Kahneman (1992).

Based on the preliminary interview conducted by the authors in June 2013 toward 30 IWMW, it is known that 25 of them (legal and/or illegal IWMW) stated that working as IWMW in itself is a "proud and prestigious" job. In addition, 24 persons stated that their family congratulates them and feels happy. The rationale is that to become IWMW, especially the legal IMWM, requires difficult undertaking as well as requirements that are not easily met; therefore, it is a "competitive" and "high status" job for them among their peers. Moreover, they have to wait for a long time for their departure. While waiting for their departure, IWMW will be gathered in shelters to learn skills and proficiencies. In addition, data show that most migrant workers in Malaysia now have prominent jobs, and senior positions are filled by many Indonesian people (BNP2TKI, 2014).

The impetus to migrate as IWMW, besides coming from the pressure of poverty and scarcity of employment opportunity, is also stimulated by the success of other IWMW that come home from abroad (Mashud, 2010). Meanwhile, according to Supriyoko (1990), factors that cause Indonesian women to choose foreign countries as their work place can be classified as intrinsic and extrinsic factors. The desires to play a role in raising the dignity of self as well as their families are the intrinsic factors. Becoming IWMW is viewed as an effort to raise their socio-economic status and prestige. They have a tendency to flaunt the wealth that they obtained from their activity of working abroad (Mashud, 2010). This study tried to capture this phenomenon by using the construct of social dominance orientation. 
Social dominance orientation (SDO) measures individual's preference for hierarchy in every social system and dominance toward inferior group or individuals (Sidanius \& Pratto, 2001; Pratto, Sidanius, Stallworth, \& Malle, 1994). People with high SDO are those who believe that life is divided into structures namely high and low status. Those in the high status are winners, have the power, or hold all of the positive values.

The SDO framework consists of three assumptions (Sidanius \& Pratto, 2001). First assumption is that the human is a creature that tends to be arranged based on hierarchical groups, where at least one group or individual is on top, and another group or individual is below. Second assumption, the hierarchy or level can be based on age, gender, social class, race, nationality, religion and other characteristics. They can be used to differentiate between different groups or individuals. The third assumption is that the individual must balance the power within themselves between the hierarchies of groups or individuals (Zander, 2008). Social dominance orientation is often conceptualized as a group-based phenomenon. However, it is also known that social dominance orientation is not only group-based but also reflects interpersonal dominance (Sidanius \& Pratto, as cited in Zander, 2008).

Social dominance orientation does not only influence one's social, political and ideological life, but also her/his whole life (Ho et al., 2011), e.g., the type of work they are looking for or subject that they wish to study (Haley \& Sidanius, as cited in Ho et al., 2011). According to what is presented by Supriyoko (1990), becoming IWMW is considered as the path one chooses to raise their social class also the dignity of themselves and their close relatives. Therefore, the first hypothesis of this study (H1) was “The higher IWMW's SDO, the higher their attitude toward risk."

Perceived scarcity of the opposite sex was suggested as one of the triggers for Indonesian women to decide in becoming IWMW. The limited numbers of men in comparison to women, based on the evolutionary psychological perspective, force women to be smart in attracting men because established and highly qualified men are more selective in choosing their spouse as well as have certain established criteria. By becoming IWMW, a woman hopes to find highly qualified partner. A woman is not simply looking for a sex partner but also for he that can contribute to their future as well as provide good offspring (Gangestad \& Simpson, as cited in Durante, Griskevicius, Simpson, Cantu, \& Tybur, 2012). When scarcity in men population occurred, women find it difficult in maintaining partners that have willingness and abilities to invest on the future of their offspring. It is explained in scarcity theory of the opposite sex which focused on the imbalance numbers between the reproductive men and women, which is referred to as operational sex ratio (Durante, Griskevicius, Simpson, Cantu, \& Tybur, 2012). Theoretical review by Supriyoko (1990) showed that one of the extrinsic factors of Indonesian women becoming IWMW is due to sex ratio in their area. Therefore, the second hypothesis of this study (H2) was "The higher IWMW's perceived number of opposite sex, the lower their attitude toward risk."

This study hypothesized the predictive relationship between social dominance orientation, perceived scarcity of the opposite sex, and attitude toward risk on IWMW, as shown in the Figure 1.

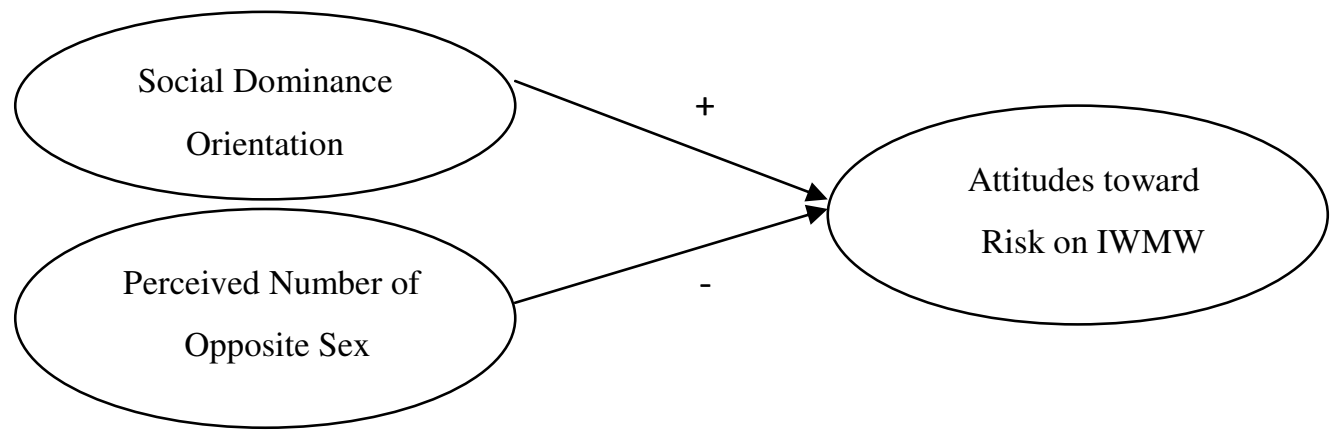

Notes. (+) positive predictive correlation

(-) negative predictive correlation

Figure 1. Hypothetical model 


\section{Methods}

The research design used for this study was quantitative non-experimental and predictive correlational. The population of this study was IWMW that will be departing overseas. Those IWMW are going to work abroad in informal sectors for the first time. The participants of this study were 18-35 years old IWMW $\left(n=258 ; M_{\text {age }}=\right.$ 20.089 years old; $S D_{\text {age }}=5.142$ years old) taken with convenience sampling technique. Their levels of education were as follow: Elementary School (68), Junior High School (153), Senior High School (37). Most of them are Javanese (159) and Sundanese (58). Locations of this study were shelters for IWMW located in East Jakarta and the institution of National Agency for Placement and Protection of Indonesian Workers (BNP2TKI). Pilot study to test the validity and reliability of measuring instruments of this study was conducted on 50 participants outside the participants of field research.

Instrument for measuring the level of SDO on IWMW was adapted from Social Dominance Orientation Scale (Pratto, Sidanius, Stallworth, \& Malle, 1994; Sidanius \& Pratto, 2001). The scale consists of 16 items. Sample items of this scale are, "To get ahead in life, it is sometimes necessary to step on others", "In getting what you want, it is sometimes necessary to use force against others", "Some people are just more worth than others", and "All humans should be treated equally" (unfavorable item; reversely scored). The response options for this scale are Strongly Disagree (score of 1), Disagree (score of 2), Somewhat Disagree (score of 3), Somewhat Agree (score of 4), Agree (score of 5), and Strongly Agree (score of 6). The reliability index (Cronbach's alpha) of the SDO measuring instrument is 0.835 . The lowest value of corrected item-total correlations is 0.251 , and the highest value is 0.732 . It can be concluded that the measuring instrument for SDO has a good item validities (corrected item-total correlations $>0.25$ ) and good scale reliability (Cronbach's alpha $>0.6)$.

Instrument for measuring the perception of IWMW toward scarcity of the opposite sex consisted of only an item which is, "Currently the number of men is more than the number of women" (single-item scale). The response options for this scale are Strongly Disagree (score of 1), Disagree (score of 2), Somewhat Disagree (score of 3), Somewhat Agree (score of 4), Agree (score of 5), and Strongly Agree (score of 6). The lower score represents the higher perceived scarcity of opposite sex.

To measure attitude toward risk, Domain-Specific Risk-Taking (DOSPERT) Scale (Weber, Blais, \& Betz, 2002; Blais \& Weber, 2006) was used. Participants indicated the possibility of their involvement in domain-specific risky activities. DOSPERT is a psychometric scale that assesses attitude toward risk-taking in five domains. They are: financial, with sample item, "Risking daily income for gambling", health or safety, with sample item, "Consuming five or more servings of alcohol in a single evening", recreation, with sample item "Going camping in the wilderness", ethics, with sample item, "Revealing a friend's secret to someone else", and social, with sample item, "Showing disapproval toward superior regarding a major issue". The response options for this scale are Strongly Disagree (score of 1), Disagree (score of 2), Somewhat Disagree (score of 3), Somewhat Agree (score of 4), Agree (score of 5), and Strongly Agree (score of 6). The reliability index (Cronbach's alpha) of this instrument is 0.964 . The lowest value of corrected item-total correlations is 0.268 and the highest value is 0.907 . It can be concluded that the measuring instrument for risk attitude has good item validities (corrected item-total correlations $>0.25$ ) and good scale reliability (Cronbach's alpha $>0.6$ ). Data analysis technique employed was multiple linear regression analysis.

\section{Results}

Multiple linear regression analysis shows $F(2,256)=66.186, p<0.01 ; R^{2}=0.343$. Those mean that SDO and perceived number of the opposite sex are simultaneously able to predict attitude toward risk on IWMW. The predictors contribute as much as $34.3 \%$ on attitudes toward risk. $\mathrm{H} 1$ and $\mathrm{H} 2$ were supported by empirical data. Based on the beta value, SDO positively predict attitude toward risk $(\beta=0.618, p<0.01$; see Table 1$)$. This means that if SDO is higher than attitude toward risk of IWMW will also be higher. Perceived number of the 
Attitudes toward risk, social dominance orientation and perceived scarcity of the opposite sex

opposite sex negatively predict attitudes toward risk $(\beta=-0.159, p<0.01$; see Table 1$)$. It means that the perception of fewer or scarcer men will raise more positive attitude toward risk on IWMW.

\section{Table 1}

Multiple Linear Regression Analysis Predicting Attitude toward Risk on Indonesian Woman Migrant Workers (n $=258)$

\begin{tabular}{lccccc}
\hline \multicolumn{1}{c}{ Independent Variables } & $B$ & $S E B$ & $\beta$ & $t$ & $p$ \\
\hline Social Dominance Orientation & 2.745 & 0.239 & 0.618 & 11.474 & 0.000 \\
Perceived Number of the Opposite Sex & -3.073 & 1.043 & -0.159 & -2.947 & 0.004 \\
\hline
\end{tabular}

Note. $R^{2}=0.343$

\section{Discussion}

This study found that SDO can predict risk attitude in a positive way. One of the major characteristics of people with high SDO is maintaining inequality between persons or social groups or sustaining the existing social hierarchy (Pratto, Sidanius, Stallworth, \& Malle, 1994). This social hierarchy has several bases. It can be based on age (e.g.: older people have higher status than younger people), sex (e.g.: men have higher status than women), or any social group (arbitrary; e.g.: people of religion X has higher status than of religion $\mathrm{Y}$, tribe $\mathrm{X}$ has higher status than tribe Y). In this study, women becoming IWMW are viewed to have higher status, more superior, than the out-group, i.e. non-IWMW. In this Indonesian context, SDO uses occupation or profession or role as a base. Duckitt and Sibley (2010) theorize that SDO is activated by competition. In this study, what is referred to as "competition" is the contest between women during scarcity of the opposite sex. Duckitt and Sibley (2010) use the perspective of evolutionary psychology stating that the social world is "ruthless" and triggers competition for survival by competing for resources. What is referred to as "resources" in this study are qualified men that are potential partners for IWMW. Principle of evolutionary psychology is "The strong wins in battle", even "by using all possible means". The way to strengthen status and position for Indonesian women, in this study, is by becoming IWMW.

In this study, becoming IWMW is assumed as behavior with experience structure similar to risky behavior. Those risks among others are cultural shock, vulnerability to scams and violence, and minimum personal and legal protection (KampungTKI, 2013). Nevertheless, risk taking is one way to become dominant or superior. Frederick Wilcox (as cited in ThinkExist.com, 2013) states "Progress always involves risk; you cannot steal second base and keep your foot on first base".

There are two explanations that can link risk attitude with dominance or superiority. One psychological variable that can connect both variables is masculinity. If so, does "masculinity" play a role in IWMW? This question requires further research. Another explanation comes from social resistance framework developed by Factor, Kawachi, and Williams (2011). According to them, marginalized group socially perform risky behavior signaling to the dominant groups that their power or authority is not without limits (Factor, Kawachi, \& Williams, 2011, p. 1293, 1296). A group that wants to become IWMW in general comes from marginalized poor families or those that overlooked or disregarded by the society. By using their theory, it can be said that IWMW group is signaling that they can also achieve ascendancy by performing risky behavior which is by becoming IWMW. Positive attitude toward risk can be viewed as a mean to show dominance that will create a positive impression, telling the world that they deserve a better partner, or other better rewarding matters.

In this regard, social dominance and system justification must be differentiated. As previously described, social dominance legitimizes maintaining inequality between persons or groups; this is similar to system justification where low status group views their inferior position in the social system as justified or legitimate. However, Brandt (2013, p. 767) said: "A recent meta-analysis on status differences in SDO found that low-status social groups were not on average supportive of the unequal social conditions that they are subjected to." It means that people with low SDO may have a desire to move up to higher status, refusing the status quo, not 
wanting continuously to be at the bottom. Nevertheless, once they are at the top level of the hierarchy, they tend to license their top position (Brandt, 2013; Brandt \& Reyna, 2012).

This study found that perceived number of opposite sex can predict risk attitude in a negative way. The relationship between sex ratio and risky behaviors had been studied, but the study focus more on risky sexual behavior. For example, Gantz (2009, p. 57) through studying numerous empirical researches found:

An imbalanced sex ratio within a specific geographic area affects the mate availability within that area, potentially leading to more risky sexual behavior by the scarcer gender.

Newer findings in Asia (China) also support Gantz's findings. Research conducted by South and Trent (2010) in China found that imbalance between sex population increases early, higher frequency of sex behavior and partner switching as well as infection of sexually transmitted disease. Furthermore, Gibson (2011) specifically found that men who in their demographical area experience scarce number of women are more likely to be suicide attackers. Suicide attack is a very extreme risky behavior.

The relationship between sex ratio and risky behavior had also been studied in financial behavior (saving, borrowing, and spending) by Griskevicius et al. (2012). According to research by Griskevicius et al., a condition of too many men causes competition among them that make them spend more money during courtship with the opposite sex. It is in line with evolutionary psychological theory which states that: "as sex ratio becomes male-biased and women become scarce ... men should want immediate rewards" (Griskevicius et al., 2012).

Those studies exposed above are objective-epidemiologic in nature. Result of this present study is different from Gantz's (2009) research because this study took subjective data, namely individuals' perception regarding sex ratio in their area, whether there are more men or women. In addition, this study is conducted on women, not men. So far women are less represented in researches relating sex ratio with risky behavior. It might be because risky behaviors are also often linked with the biological bases of men, namely testosterone hormone. In addition, this study linked the perception of sex ratio with risky behavior in general, not just those related with sexual and financial behavior. By using DOSPERT as a measuring tool, risky behavior of various fields can be measured.

This perceptual psychology research result support previous studies. The explanation offered by Griskevicius et al. (2012) can also be used to explain the result of the current study, i.e.:

An abundance of rivals should lead men to value immediate rewards because there is an important trade-off between acquiring immediate resources and waiting in hopes of acquiring more of better quality resources in the future.

The statement above provides insight in explaining why the scarcity of opposite sex causes women to having positive attitude toward risk, or by performing risky behavior (becoming IWMW). They actually strive for immediate rewards (having qualified partners) in the shortest way. The desire to be IWMW is a popular heuristic among Indonesian women to gain much money in a short period, hence they can buy cosmetic, fashion, and things that will improve their status in the eyes of society. The risky behavior can immediately increase self-image. Increased self-image correlates positively with the possibility of obtaining rewarding thing (Fuller Barnett, Hester, Relyea, \& Frey, 2007).

Although Fuller et al.'s (2007) research was done in the context of the organization, it has a pivotal significance. They found through empirical research that in a competitive situation between workers, employees that want to increase their positive image of their competency will perform "voice behavior" or suggest initiative ideas that challenge the status quo. This behavior has several benefits in the form of positive impression, in addition to innovation for the organization. However, voice behavior also carries risks, especially if the behavior is perceived as complaints or personal criticism. Fuller et al. (2007) showed that voice behavior is functionally aimed for impression management, especially when there is interaction between high self-monitoring and low performance. Implication of Fuller et al.'s finding can be extended to this study. IWMW in general are women 
Attitudes toward risk, social dominance orientation and perceived scarcity of the opposite sex

who have low competency (Febriani, 2011), or in Fuller's theory termed as "low performance". This study posited that the low performance of IWMW brings about positive attitude toward risk.

\section{Conclusion}

This study concludes that social dominance orientation and perceived scarcity of the opposite sex can predict attitudes toward risk on Indonesian woman migrant workers (IWMW). In this study, there is a limitation. The majority of research participants have low level education. Due to the condition, researcher needs to help clarifying the semantic aspects of the psychological scales' items face by face when distributing the instruments. This research has an implication for a new perspective on how we should look at and assess the risky attitude and behavior of migrant workers. So far, we might have been simplistic in attributing their attitudes and behavior, i.e. as a representation of the ones that hopeless or helpless (e.g., Armour, 2001). However, the findings of this study provide the nuance of self-empowerment of migrant workers, in line with the perspective of positive psychology (cf. Zhang, Cui, Iyer, Jetten, \& Hao, 2014), which arises from the psychosocial reality of them.

\section{References}

Armour, S. (2001). Part 1: Some foreign household workers enslaved. Retrieved from http://usatoday30.usatoday.com/money/general/2001/11/19/cover.htm

Blais, A.-R., \& Weber, E. U. (2006). A domain-specific risk-taking (DOSPERT) scale for adult populations. Judgment and Decision Making, 1, 33-47.

BNP2TKI. (2014). Angka remitansi TKI tembus Rp 60 Triliun [Remittance statistics of migrant workers break through $R p 60$ trillion]. Retrieved from http://www.bnp2tki.go.id/read/9296/Angka-Remitansi-TKI-Tembus-Rp-60-Triliun

Brandt, M. J. (2013). Do the disadvantaged legitimize the social system? A large-scale test of the status-legitimacy hypothesis. Journal of Personality and Social Psychology, 104(5), 765-785. http://dx.doi.org/10.1037/a0031751

Brandt, M. J., \& Reyna, C. (2012). Social dominance or system justification? The acceptance of inequality and resistance to social change as unique system-relevant motivations. Retrieved from http://papers.ssrn.com/sol3/papers.cfm?abstract_id=2165690

Crozier, W. R, Ranyard, R., \& Svenson, O. (Eds.). (2002). Decision making: Cognitive models and explanations. London: Routledge.

Duckitt, J., \& Sibley, C. G. (2010). Personality, ideology, prejudice, and politics: A dual-process motivational model. Journal of Personality, 78(6), 1861-1893. http://dx.doi.org/10.1111/j.1467-6494.2010.00672.x

Durante, K. M., Griskevicius, V., Simpson, J. A., Cantu, S. M., \& Tybur, J. M. (2012). Sex ratio and women's career choice: Does a scarcity of men lead women to choose briefcase over baby. Journal of Personality and Social Psychology, 103(1), 121-134. http://dx.doi.org/10.1037/a0027949

Emmers, R. (2003). The threat of transnational crime in Southeast Asia: Drug trafficking, human smuggling and trafficking, and sea piracy. Retrieved from http://pendientedemigracion.ucm.es/info/unisci/revistas/Ralf.pdf

Factor, R., Kawachi, I., \& Williams, D. R. (2011). Understanding high-risk behavior among non-dominant minorities: A social resistance framework. Social Science \& Medicine, 73, 1292-1301. http://dx.doi.org/10.1016/j.socscimed.2011.07.027

Febriani. (2011). Peningkatan kualitas pendidikan dan ketrampilan TKI menuju kesetaraan upah di luar negeri: Sebuah rekonstruksi [Improvement the quality of education and skills of Indonesian migrant workers towards equal pay in foreign countries: A reconstruction]. Jurnal Manajemen dan Kewirausahaan, 2(1), 42-61.

Fuller, J. B., Barnett, T., Hester, K., Relyea, C., \& Frey, L. (2007). An exploratory examination of voice behavior from an impression management perspective. Journal of Managerial Issues, 19(1), 134-151.

Gant, Z. C. (2009). Social environmental factors and their effects on risky sexual behavior: A multilevel 
approach. Unpublished doctoral dissertation, Epidemiological Science, University of Michigan, Ann Arbor, United States.

Gibson, K. R. (2011). The roles of operational sex ratio and young-old ratio in producing suicide attackers. Unpublished doctoral dissertation, Anthropology Department, College of Social \& Behavioral Science, University of Utah, Salt Lake City, United States.

Griskevicius, V., Tybur, J. M., Ackerman, J. M., Delton, A. W., Robertson, T. E., \& White, A. E. (2012). The financial consequences of too many men: Sex ratio effects on saving, borrowing, and spending. Journal of Personality and Social Psychology, 102(1), 69-80. http://dx.doi.org/10.1037/a0024761

Handayani, R. (2012, June 27). Perempuan dalam pusaran tenaga kerja global [Women in the vortex of a global workforce]. Radar Lampung. Retrieved from http://www.radarlampung.co.id/read/opini/50564-perempuan-dalam-pusaran-tenaga-kerja-global

Harris, C. R., \& Jenkins, M. (2006). Gender differences in risk assessment: Why do women take fewer risks than men? Journal of Judgment and Decision Making, 1(1), 48-63.

Ho, A. K., Sidanius, J., Pratto, F., Levin, S., Thomsen, L., Kteily, N., Sheehy-Skeffinton, J. (2011). Social dominance orientation: Revisiting the structure and function of a variable predicting social a political attitudes. Personality and Social Psychology Bulletin, 20(10), 1-24.

Holton, G. A. (2004). Defining risk. Financial Analysts Journal, 60(6), 19-25. http://dx.doi.org/10.2469/faj.v60.n6.2669

Johnson, V. (2009). Risk style, regulatory focus, and the situation in risky choice decision making. Unpublished doctoral dissertation, Graduate Faculty of Auburn University, Alabama.

Kahneman, D. (2011). Thinking, fast and slow. New York: Farrar, Straus and Giroux.

KampungTKI. (2013). Resiko, manfaat dan tantangan menjadi TKI [Risks, benefits and challenges of being Indonesian migrant workers]. Retrieved from http://www.kampungtki.com/baca/14783

Kistyarini. (2013). Bertaruh nyawa menjadi TKI [Bet life to become migrant worker]. Retrieved from http://regional.kompas.com/read/2013/10/16/1745182/Bertaruh.Nyawa.Menjadi.TKI

Mashud, M. (2010). Perspektif fenomenologi tentang trafficking TKW [Phenomenological perspective on trafficking experienced by Indonesian woman migrant workers]. Masyarakat, Kebudayaan, dan Politik, 2l(2), 146-154.

Pratto, F., Sidanius, J., Stallworth, L. M., \& Malle, B. F. (1994). Social dominance orientation: A personality variable predicting social and political attitudes. Journal of Personality and Social Psychology, 67(4), 741-763. http://dx.doi.org/10.1037/0022-3514.67.4.741

SapulidiNews. (2014). Gila, Rp 184 M potensi klaim asuransi TKI tak tertangani [Wow, 184 billion potential insurance claims of migrant workers are not well managed]. Retrieved from http://sapulidinews.com/guru/berita.php?id=2022

Shehadeh, N., \& McCoy, H. V. (2014). Risky sexual behaviors: The role of ethnic identity in HIV risk in migrant workers. Journal of the Association of Nurses in AIDS Care, 25(4), 330-340. http://dx.doi.org/10.1016/j.jana.2013.09.001

Sidanius, J., \& Pratto, F. (2001). Social dominance: An intergroup theory of social hierarchy and oppression. Cambridge: Cambridge University Press.

South, S. J., \& Trent, K. (2010). Imbalanced sex ratios, men's sexual behavior, and risk of sexually transmitted infection in China. Journal of Health and Social Behavior, 51(4), 376-390. http://dx.doi.org/10.1177/0022146510386789

Supriyoko (1990, July). Tenaga kerja wanita Indonesia: Latar belakang dan catatannya [Indonesian woman migrant workers: Background and notes]. Paper presented at Forum Diskusi Panel Harkat Wanita Indonesia sebagai Tenaga Kerja Wanita di Luar Negeri, Wanita Tamansiswa Cabang Sarjanawiyata, Yogyakarta [Paper presented at Panel Discussion Forum of Indonesian Woman's Dignity as Labor Abroad, Woman Tamansiswa Branch Sarjanawiyata, Yogyakarta]. Retrieved from http://journal.amikom.ac.id/index.php/KIDA/article/viewFile/5146/2819

ThinkExist.com (2013). Frederick Wilcox's quotes. Retrieved from http://thinkexist.com/quotation/progress_always_involves_risk-you_can-t_steal/10810.html 
Attitudes toward risk, social dominance orientation and perceived scarcity of the opposite sex

Tversky, A., \& Kahneman, D. (1992). Advances in prospect theory: Cumulative representation of uncertainty. Journal of Risk and Uncertainty, 5(4), 297-323. http://dx.doi.org/10.1007/BF00122574

Utami, N. (2012). Tinjauan yuridis pelaksanaan asuransi tenaga kerja dalam memberikan perlindungan terhadap penempatan tenaga kerja Indonesia di luar negeri [Judicial review of the implementation of employment insurance in providing protection for the placement of Indonesian workers abroad]. Retrieved from http://pustaka.unpad.ac.id/archives/117820/\#

Weber, E. U., Blais, A.-R., \& Betz, N. E. (2002). A domain-specific risk-attitude scale: Measuring risk perceptions and risk behaviors. Journal of Behavioral Decision Making, 15, 263-290. http://dx.doi.org/10.1002/bdm.414

Zander, S. (2008). Acculturation, perceived social dominance orientation, and perceived social support among European international students. Unpublished doctoral dissertation, University of Oklahoma, Norman, OK, United States.

Zhang, A., Cui, L., Iyer, A., Jetten, J., \& Hao, Z. (2014). When reality bites: Hopeful thinking mediates the discrimination-life satisfaction relationship. Analyses of Social Issues and Public Policy, 14(1), 379-393. http://dx.doi.org/10.1111/asap.12034 
Rizkytha, I. Z., \& Abraham, J. 